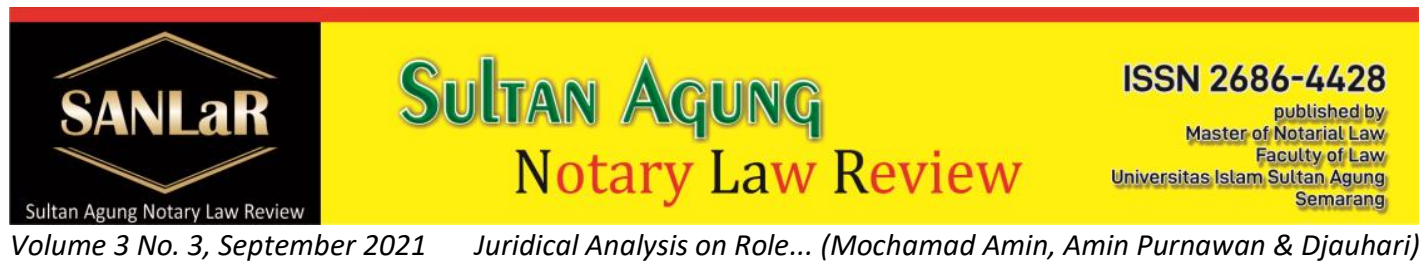

\title{
Juridical Analysis on Role \& Responsibility of Land Office in Multiple Land Certificates
}

\author{
Mochamad Amin*), Amin Purnawan ${ }^{* *}$ and Djauhari**) \\ ${ }^{*}$ Faculty of Law, Universitas Islam Sultan Agung (UNISSULA) Semarang, E-mail: \\ mochamadamin@gmail.com
}

$\left.{ }^{* *}\right)$ Faculty of Law, Universitas Islam Sultan Agung (UNISSULA) Semarang, E-mail: amin.p@unissula.ac.id

${ }^{* *}$ Faculty of Law, Universitas Islam Sultan Agung (UNISSULA) Semarang, E-mail:
djauhari@unissula.ac.id

Abstract. The imbalance between the supply of land and the need for land can lead to various land disputes, including the emergence of cases of double certificates. The Basic Agrarian Law lays the foundation for realizing legal certainty and legal protection for all Indonesian people. According to Article 19 of the UUPA Number 5 of 1960 which was followed up with Article 3 letter a of Government Regulation Number 24 of 1997 concerning the Purpose of Land Registration. In Indonesia, the institution that has a close relationship with land is the National Land Agency or BPN which has the task of carrying out government duties in the land sector in accordance with the provisions of the legislation. The objectives of this research are, one to find out and analyze the causes of the occurrence of double land certificates at the Land Office, two to identify and analyze the responsibilities of the Land Office in the case of multiple land certificates, three to identify and analyze the obstacles and solutions to the responsibilities of the Land Office in the completion of double land certificates. The approach method used in this research is empirical juridical, namely analyzing the problem by combining legal materials which are secondary data with primary data obtained in the field. The research specifications in this study are descriptive analytical. Types and sources of data, namely primary data are data. obtained from the field. secondary data, namely data obtained from or derived from library materials, data collection techniques with interviews, literature studies, document studies. Then the author analyzes qualitatively which is then presented descriptively.

Keywords: Juridical; Responsibility; BPN; Double; Certificate. 


\section{Introduction}

The rapid population growth and increasing development in our country have resulted in the need for land being felt to be increasing and urgent, while the land supply is increasingly narrow and difficult to own, it is not impossible if the price of land increases from time to time. The imbalance between the supply of land and the need for land can lead to various land disputes. Broadly speaking, the typology of cases in the land sector can be divided into five groups: ${ }^{1}$ one, cases relating to people's cultivation of plantation lands, forestry and others. two, cases relating to violations of land reform regulations. three, cases relating to access to land provision for plantations. four, civil disputes relating to land issues. five, disputes relating to ulayat land.

Land conflicts nowadays often occur due to: ${ }^{2}$ Unbalanced and unequal land ownership/control, incompatible use of agricultural and non-agricultural land, lack of partiality to the economically weak community, lack of recognition of the rights of customary law communities to land (ulayat rights), weak position of the community holding rights to land. land in land acquisition, land issues in certificate issuance (Long and expensive land certificate issuance process, fake certificates, overlapping certificates, certificate cancellation).

So to protect parties with an interest in land issues, legal certainty over land is an absolute thing that must exist in order to maintain security and stability in development and to realize land rights certainty. law for all Indonesian people. According to Article 19 of the UUPA Number 5 of $1960^{3}$ which is followed up by Article 3 letter a of Government Regulation Number 24 of 1997 concerning the Purpose of Land Registration.

"To provide legal certainty and legal protection to holders of rights to a parcel of land, apartment units and other registered rights so that they can easily prove themselves as holders of the rights in question.

The legal consequence of land registration is in the form of a letter of proof of land rights which is referred to as a land certificate to the holder of the land rights concerned as strong evidence. As stated in Article 32 paragraph (1) of Government Regulation Number 24 of 1997 concerning land registration that:

\footnotetext{
${ }^{1}$ Edi As'Adi, 2000, Hukum Acara Perdata dalam Prespektif Mediasi (ADR) di Indonesia, Graha IImu, Yogyakarta, p. 1.

${ }^{2}$ Lutfi I Nasoetion, 2002, Konflik Pertanahan (Agaria) Menuju Keadilan Agraria), Yayasan AKATIGA, Bandung, p. 112.

${ }^{3}$ Article 19 paragraph (1) of the UUPA Number 5 of 1960 states that, to ensure legal certainty, the government shall conduct land registration throughout the territory of the Republic of Indonesia according to the provisions stipulated by a Government Regulation.
} 
"Certificate is a letter of proof of rights that applies as a strong means of proof regarding the physical data and juridical data contained therein, as long as the physical data and juridical data are in accordance with the data contained in the letter of measurement and the book of land rights in question."

The land title certificate issued by the Land Office is in the form of a land title certificate involving the applicant, adjoining land owners, village officials and related agencies to obtain an explanation of the documents as the basis for the rights related to the certificate application, so that the explanation from related parties have the opportunity to arise a certificate of legal disability. ${ }^{4}$

Along with the high value and benefits of land, many people try to obtain proof of land ownership by having fake certificates, where the data on the certificate does not match what is in the land book. The number of fake certificates is quite a lot, causing vulnerability. Generally, fake certificates are made on land that is still vacant and has a high value using the old certificate blank. The forgery of certificates occurs because they are not based on the correct rights base, such as the issuance of certificates based on a forged certificate of ownership. other forms are in the form of BPN stamps and falsification of land data. ${ }^{5}$ Although land registration has been carried out, there are still disputes over land rights in the midst of the community which have even reached the courts, which resulted in the blocking of the certificate by the local Land Office. The application for blocking the certificate can be made by the court because of a lawsuit, including due to the occurrence of multiple certificates, debts or due to bankruptcy and others ${ }^{6}$.

Based on the things that have been stated above, this research focuses on the land office in the presence of double certificates, by formulating several problems as follows: What are the causes of double land certificates at the Land Office? What are the responsibilities of the Land Office in the case of multiple land certificates? What are the obstacles and solutions to the responsibilities of the Land Office in the completion of double land certificates.

4 Ali Achmad Chomzah, 2003, Hukum Pertanahan Seri Hukum Pertanahan III-Penyelesaian Sengketa Hak Atas Tanah dan Seri Hukum Pertanahan IV-Pengadaan Tanah Instansi Pemerintah, Prestasi Pustaka, Jakarta, p.18.

${ }^{5}$ Ali Achmad Chomzah, 2002, Hukum Pertanahan, Prestasi Pustaka, Jakarta, p. 137.

${ }^{6}$ Deen, Thaufiq., Ong Argo Victoria \& Sumain. (2018). Public Notary Services In Malaysia. JURNAL AKTA: Vol. 5, No. 4, 1017-1026. Retrieved from http://jurnal.unissula.ac.id/index.php/akta/article/view/4135 


\section{Research Methods}

The approach used in this research is empirical juridical, namely analyzing the problem by combining legal materials which are secondary data with primary data obtained in the field. a condition or other symptoms. Types and sources of data, namely primary data is data obtained from the field. secondary data, namely data obtained from or derived from library materials, data collection techniques with interviews, literature studies, document studies. Then the writer analyzes qualitatively which is then presented descriptively. Based on the description that has been stated in the problems above,to find out and analyze the causes of double land certificates at the Land Office, second uTo find out and analyze the responsibilities of the Land Office in the event that there are multiple land certificates, third uTo identify and analyze the obstacles and solutions to the responsibilities of the Land Office in the completion of double land certificates.

\section{Result and Discussion}

\subsection{Causes of Double Land Certificates at the Land Office}

Land conflicts that have occurred so far have broad dimensions, both horizontal conflicts and vertical conflicts. The most dominant vertical conflict is between the community and the government or state-owned companies and private companies. For example, one of the cases that often occurs today is the case of double certificates. Not a few victims who fell because of questioning or defending just a few squares of land. From year to year, the number of cases in the land sector in Indonesia continues to increase. In just two years, the number of land cases reported by the National Land Agency (BPN) of the Republic of Indonesia increased by five thousand cases.

Another cause of double land disputes is the high economic value of land and land is a symbol of existence and social status in the community, resulting in vertical and horizontal land conflicts. The strategic and special meaning and value of land encourages everyone to own, maintain and care for their land properly, if necessary, defend it with all their might until the last drop of blood. The roots of conflicts and land disputes that are multidimensional in nature cannot be seen as mere legal issues, but are also related to other nonlegal variables, among others, the weak regulation of land certification which has not reached $50 \%$.

Reason the occurrence of double land certificates at the land office, namely:

a. Lack of transparency of information regarding land ownership. 
b. The dishonesty of village officials and the applicant, in this case the land owner, in providing information to BPN.

c. Economic value of land and land that is used by the community as a symbol of social existence in society, so that everyone uses all means to defend it.

d. Weak regulations even though land disputes are multidimensional.

e. The overlapping of decisions issued by interested state institutions regarding the ownership of land rights.

f. Interpretation among the people who misinterpret which land is customary or has customary rights and which is land that is not owned by custom or state land.

g. The problem of land reform which until now has not been solved.

h. As well as the existence of natural disasters that cause damage to proof of ownership of land rights and shifting of land after the disaster.

i. And the most complex thing is the lack of utilization of land registration maps and computerized systems that are not yet modern.

Those are some of the things that cause land disputes and double certificates, of course there are many other things that can cause this to happen.

\subsection{Responsibilities of the Land Office in the Case of Multiple Land Certificates}

BPN is the only institution or institution in Indonesia that is given the authority to carry out the mandate in managing the land sector, in accordance with Act No. 10 of 2006 concerning the National Land Agency. The basis for the formation of BPN is Presidential Decree no. 26 of 1988. As an operational guide for BPN, the leadership of this institution then issued Decree No. 11/KBPN/1988 in conjunction with the Decree of the Head of BPN No. 1 of 1989 concerning the Organization and Work Procedure of BPN in Provinces and Regencies/Municipalities.

According to the regulation of the Head of BPN-RI No. 3 of 2006 concerning the organization and working procedures of BPN-RI, the study and handling of land disputes and conflicts is the area of Deputy $V$ in charge of:

a. Directorate of land conflicts

b. Directorate of land disputes

c. Directorate of land cases (Article 346 Regulation of the Head of BPN-RI No. 3 of 2006) 
Responsibilities of the Land Office in the Case of Multiple Land Certificates. BPN also has certain mechanisms in handling and resolving land cases or disputes, in this case including multiple certificate disputes, namely:

a. Land disputes are usually recognized by BPN from complaints.

b. Complaints are followed up by identifying problems. It is confirmed whether the problem element is under the authority of BPN or not.

c. If it is indeed the authority, then BPN examines the problem to prove the veracity of the complaint and determine whether the complaint is justified for further processing.

d. If the results of the research need to be followed up by examining administrative and juridical physical data, the head of the office can take steps to prevent mutations (status quo).

e. If the problem is strategic, it is necessary to establish several work units. If it is political, social, and economic, the team will involve institutions such as the DPR or DPRD, the Ministry of Home Affairs, the relevant local government.

f. The team will compile a report on the results of the research to become a recommendation for problem solving.

The form of responsibility of the land office in handling land disputes in this case double certificates is resolved in 3 (three) ways, namely:

a. Settlement directly by the parties by deliberation

The basis for deliberation for consensus is implied in Pancasila as the basis of Indonesian social life and in the 1945 Constitution. Deliberations are conducted outside the court with or without a mediator. Mediators are usually from parties with influence, such as the Village Head, customary leaders and of course the National Land Agency. In the settlement of land disputes through deliberation, one condition is that the dispute is not in the form of a determination of land ownership which can give rights or eliminate someone's rights to the disputed land, and between the disputing parties have a fairly close westernity and still adhere to local customary law.

b. Through arbitration and alternative dispute resolution:

Arbitration is the settlement of a case by one or several arbitrators (judges) who are appointed based on the agreement/approval of the parties and it is agreed that the decisions taken are binding and final. The main requirement that must be done to be able to use arbitration as a dispute resolution is the existence of an agreement made in writing and agreed by the parties.). If an arbitration clause has been written in a contract or an arbitration agreement, and the other party wishes to 
resolve the legal issue to the court, then the litigation must be postponed until the arbitration process is completed in an arbitration institution. Thus the court must and must recognize and respect the authority and function of the arbitrator.

c. Settlement of disputes through the judiciary: In accordance with applicable regulations in Indonesia, in general, the settlement of land disputes related to ownership disputes is submitted to the general court, disputes over decisions of the National Land Agency through the State Administrative Court and disputes concerning waqf land are submitted to the Religious Courts.

\subsection{Obstacles and Solutions to Responsibilities of the Land Office in Completing Double Land Certificates}

Obstacles in completing double land certificates in Cilacap Regency. The occurrence of double certificates has indirectly opened up opportunities for legal violations such as fake certificates, misuse of certificates, double certificates influenced by internal and external factors. Internal factors include:

1. Internal Factors:

a. The non-implementation of the provisions of the Basic Agrarian Law and its implementing regulations in a consistent, consistent and responsible manner, besides that there are still people who act for personal gain without regard to the rights of others.

b. Lack of functioning of the supervisory apparatus so as to provide opportunities for subordinate officers to act deviantly in the sense of not carrying out their duties and responsibilities according to their oath of office.

c. The inaccuracy of Land Office officials in issuing land certificates, namely the documents that are the basis for the issuance of certificates are not examined carefully, which may not meet the requirements as determined by the applicable laws and regulations.

2. External factors include:

a. The community is still not aware of the laws and regulations on land, especially regarding the procedure for making land certificates.

b. The land supply is not balanced with the number of enthusiasts who need land.

c. The development resulted in the need for land increasing while the land supply was very limited so as to encourage the shift of land 
functions from agricultural land to non-agricultural land, resulting in soaring land prices.

\subsection{Solutions for the responsibility of the land office in the completion of double land certificates}

The National Land Agency always seeks a solution to the double certificate dispute resolution, BPN is also authorized to negotiate, mediate and facilitate the disputing parties and initiate an agreement between the parties. BPN regional offices, namely in the Province and Regency/Municipality, can only arrive at a decision on problem solving, while the follow-up to land administration is still carried out by the Central BPN.

To minimize land disputes in this case double certificates, the roles performed by BPN as public servants include:

a. Reviewing and managing data to resolve cases in the land sector.

b. Accommodate community complaints in the event of a dispute over land and seek to resolve it amicably by going to the field to carry out re-measurements involving the disputing parties and related village officials.

c. Reviewing and preparing draft decisions regarding settlement of land disputes

d. Reviewing and preparing the concept of a decision on the cancellation of land rights that are administratively flawed and based on the peace deed above

e. The results of the settlement are marked and formulated in the Minutes of Land dispute settlement witnessed by village officials and village elders, and if necessary strengthened through a deed of peace drawn up by an in the presence of a notary.

$f$. If the above encounters obstacles and there is no agreement between the disputing parties, the last resort is to invite the disputing parties to take legal action in accordance with applicable regulations.

g. Prepare answer memory materials, prepare appeal memorandum, memory/counter memory for cassation, memory/counter memory for review of cassation on cases filed through the courts against double and legal entities that are detrimental to the state.

h. Collect data on land issues and disputes.

i. Documentation. 


\section{Closing}

The cause of multiple land disputes is the high economic value of land and land is a symbol of existence and social status in the community, resulting in vertical and horizontal land conflicts. The strategic and special meaning and value of land encourages everyone to own, maintain and care for their land properly, if necessary, defend it with all their might until the last drop of blood. The roots of conflicts and land disputes that are multidimensional in nature cannot be seen as mere legal issues, but are also related to other non-legal variables, among others, the weak regulation of land certification which has not reached $50 \%$. The form of responsibility of the land office in dealing with land disputes in this case double certificates is resolved in 3 (three) ways, namely first, direct settlement by the parties through deliberation, secondly through arbitration and alternative dispute resolution, and thirdly, dispute resolution through the judiciary. The National Land Agency always seeks a solution to the double certificate dispute resolution, BPN is also authorized to negotiate, mediate and facilitate the disputing parties and initiate an agreement between the parties. BPN regional offices, namely in the Province and Regency/Municipality, can only arrive at a decision on problem solving, while the follow-up to land administration is still carried out by the Central BPN.

\section{References}

\section{Journals:}

[1] Darwis Anatami, Tanggung Jawab Siapa, Bila Terjadi Sertifikat Ganda Atas Sebidang Tanah, Jurnal Hukum Samudra Keadilan Volume 12, Nomor 1, January-June $2017 \sim 1$

[2] Deen, Thaufiq., Ong Argo Victoria \& Sumain. (2018). Public Notary Services In Malaysia. JURNAL AKTA: Vol. 5, No. 4, 1017-1026. Retrieved from http://jurnal.unissula.ac.id/index.php/akta/article/view/4135

[3] Maya Anas Taqiyyah, Atik Winanti Jurnal justisia Perlindungan Hukum Pemegang Sertifikat Atas Tanah Ganda Berdasarkan Peraturan Pemerintah No.24 Tahun 1997, Vol 5, No 1 (2020) Christin Sasauw, Tinjauan Yuridis Tentang Kekuatan Mengikat Suatu Akta Notaris, LexPrivatum, Vol.lii , No. 1, Jan-Mar , 2015.

[4] Mudakir Iskandar Syah, Sertifikat Tanah Ganda Akibat Lemahnya Data Base Pertanahan, Jurnal IImiah Hukum Dirgantara Vol 4, No 2 (2014) 
[5] Rizki Riolita , Analisis Yuridis Mediasi Penal Dalam Penyelesaian Sengketa Tanah Terhadap Sertifikat Ganda Di Kantor Pertanahan Kota Semarang, Indonesian Journal Of Criminal Law Studies (Ijcls) I (1) (2016)

[6] Tata Wijayanta , Asas Kepastian Hukum, Keadilan Dan Kemanfaatan Dalam Kaitannya Dengan Putusan Kepailitan Pengadilan Niaga, Jurnal Dinamika Hukum, Vol.14,No.2, May, 2014.

Books:

[1] Al-Baghday, Abdurrahman, Serial Hukum Islam : Penyewaan Tanah Lahan, Kekayaan Gelap, Ukuran Panjang, Luas, Takaran dan Timbangan, (Bandung : Alma'arif), 1987

[2] Ali, Athif Abu Zaid Sulaiman, Ihya`Al-Aradhi al-Mawat fi al-Islam, (Makkah : Rabithah al-'Alam al-Islami), $1416 \mathrm{H}$

[3] Al-Maliki, Abdurrahman, As-Siyasah Al-Iqtishadiyah al-Mutsla, (t.tp : Hizbut Tahrir), 1963

[4] Al-Nabhani, Taqiyuddin, Al-Syakhshiyah Al-Islamiyah, Juz II, (Beirut : Darul Ummah), 2003

[5] Arie S., Perlindungan Pemilikan Tanah dari Sengketa Menurut Hukum Tanah Nasional, Tebaran Seputar Masalah Hukum Tanah, Lembaga Pemberdayaan Hukum Indonesia, 2005

[6] Basuki, Sunario, Ketentuan Hukum Tanah Nasional ( HTN ) yang Menjadi Dasar dan Landasan Hukum Pemilikan dan Penguasaan Tanah, Program Pendidikan Spesialis Notariat Fakultas Hukum Universitas Indonesia Hutagalung,

[7] Chomzah, A.A. 2002. Hukum Pertanahan, Seri Hukum Pertanahan IPemberianHak Atas Tanah Negara dan Seri Hukum Pertanahan IISertipikat dan Permasalahannya. Jakarta: Prestasi Pustaka.

[8] Chomzah, A.A. 2003. Hukum Pertanahan, Seri Hukum Pertanahan IIIPenyelesaian Sengketa Hak Atas Tanah dan Seri Hukum Pertanahan IVPengadaan Tanah Instansi Pemerintah. Jakarta: Prestasi Pustaka.

[9] Friedman, L.M. 2001. American Law An Introduction Second Edition (Hukum Amerika Sebuah Pengantar) Penerjemah Wishnu Basuki. Jakarta: PT. Tatanusa. 
[10] Ghadiy, Yasin, Al-Amwal wa Al-Amlak al-'Ammah fil Islam, (Mu`tah : Mu`assasah Raam), 1994

[11] Harsono, Boedi. 2002. Hukum Agraria Indonesia, Himpunan Peraturan- Peraturan Hukum Tanah. Jakarta : Jambatan. Revision Edition Print. 1.

[12] Isnur, Eko Yulian, Tata Cara Mengurus Segala Macam Surat Rumah Dan Tanah, Yogyakarta: Pustaka Yustisia, 2012

[13] Johansen, Baber, The Islamic Law on Land Tax and Rent, (LondonNew York-Sydney : Croom Helm), 1988

[14] Lubis Mhd., Yamin dan Abd. Rahim Lubis, Hukum Pendaftaran Tanah, Jakarta: Mandar Maju, 2008

[15] Mahasari, Jamaluddin, Pertanahan dalam Hukum Islam, (Yogyakarta : Gama Media), 2008

[16] Miles, B. Matthew dan Huberman A. Michael. 1992. Analisis Data Kualitatif. Jakarta: UI Press

[17] Moleong, L.J. 2004. Metode Penelitian Kualitatif. Bandung: PT.Remaja Rosdakarya Offset. Print. Ke-22 (Revision Edition).

[18] Murad, Rusmadi. 1991. Penyelesaian Sengketa Hukum Atas Tanah, Bandung: Alumni. Print. I,

[19] Nazir, Moh 2005. Metode Penelitian. Bogor: Ghalia Indonesia. Parlindungan, A.P.1999, Pendaftaran Tanah Di Indonesia, Bandung: Mandar Maju, Print. Pertama.

[20] Sait, M. Siraj, The Relevance of Islamic Law Land for Policy and Project Design, Makalah dalam Conference on Challenge for Land Policy and Administration, The World Bank, Washington DC, 14-15 Pebruari 2008.

[21] Salasal, Siti Mariam Malinumbay S., The Concept of Land Ownership : Islamic Perspectif, dalam Buletin Geoinformasi, Jilid 2, No 2, hlm. 285-304, Penerbitan Akademik Fakulti Kejuruteraan \& Sains Geoinformasi, Universiti Teknologi Malaysia, Skudai, Desember 2004 
[22] Sarjita. 2005. Teknik Dan Strategi Penyelesaian Sengketa Pertanahan, Yogyakarta:Tugujogja Pustaka. Edisi Kedua. Soekanto, Soerjono. 1986. Pengantar Penelitian Hukum. Jakarta:UI-Pres.

[23] Sembiring, Jimmy Joses, Cara Menyelesaikan Sengketa Diluar Pengadilan, Jakarta: Visimedia, 2011

[24] Suhartono, Titik Singgung Hak Tanggungan Atas Tanah dengan Hukum Perwakafan, (t.tp : t.p.), t.t.

[25] Sutedi, Adrian. 2009. Peralihan Hak Atas Tanah Dan Pendaftarannya. Jakarta: Sinar grafika.

[26] Syauman, Amin, Bahtsun fi Aqsam Al-Aradhiin fi Asy-Syariah AlIslamiyah wa Ahkamuhaa, (t.tp. : t.p) : t.t.

[27] Zallum, Abdul Qadim, Al-Amwal fi Daulah al-Khilafah, (Beirut : Darul Ummah) 